\title{
ISOLATION AND CHARACTERIZATION OF A POLYPEPTIDE ABSENT FROM NON-FLOCCULENT MUTANTS OF SACCHAROMYCES CEREVISIAE
}

\author{
by
}

STEEN HOLMBERG

Department of Physiology, Carlsberg Laboratory

Gamle Carlsberg Vej 10, DK-2500 Copenhagen Valby

\begin{abstract}
Keywords: Yeast genetics, SDS-gel electrophoresis, antibodies, column chromatography
\end{abstract}

\begin{abstract}
Alkaline cell extracts obtained from whole cells of a flocculent strain of Saccharomyces cerevisiae, containing the dominant gene for flocculence $F L 04$, and a nonflocculent mutant ( $F L 04$, fsul) were analyzed by sodium dodecyl sulfate-polyacrylamide gel electrophoresis. The mutant lacked a low molecular weight $(13,000)$ polypeptide present in the extract from the parent strain. This polypeptide difference was also observed when five other independently isolated non-flocculent mutants of the parent strain were analyzed. One of these five mutants was characterized genetically and also in this case was non-flocculence shown to be due to an unlinked suppressor mutation of FLO4. This suppressor gene is designated fsu2. Analysis of petites with different flocculation phenotypes further extended the correlation between non-flocculence and the absence of the polypeptide.

The polypeptide was isolated by gel filtration in the presence of sodium dodecyl sulfate followed by ionexchange chromatography on DEAE-cellulose. By electrophoretic analysis the purity of the preparation was estimated to be $95 \%$. From amino acid analysis the polypeptide was calculated to consist of 121 residues with a molecular weight of 12,900 daltons.

Differential extraction of proteins iodinated in situ by lactoperoxidase suggested an external location of the polypeptide.
\end{abstract}

\section{INTRODUCTION}

Yeast flocculation is characterized by reversible clumping of cells and rapid sedimentation of the clumps from the medium. It is dependent on the presence of divalent metal ions, especially calcium (13). The flocculation characteristics of the yeast used in brewing influence the ex- tent of fermentation and are important for the removal of cells from the fermented wort.

It has been proposed that proteins located in the yeast cell wall are involved in the floc. culation phenomenon $(10,13,16)$. Extraction with alkali of cell components from yeast strains differing in flocculation intensity have 
been used in the study of the biochemistry of flocculence $(11,22)$. The information obtained from such studies would be greatly enhanced if the strains analyzed were isogenic except for the gene or genes affecting flocculence.

In an earlier paper the isolation of non-flocculent mutants from a Saccharomyces cerevisiae strain containing the dominant gene for flocculence FLO4 was described (9). One of these mutants was characterized genetically and non-flocculence was shown to be due to an unlinked suppressor of FL04. The suppressor was designated with the symbol suf but is now renamed $f s u l$ since the symbol $S U F$ has recently been used for frame shift suppressors (4). In the present study, alkaline extracts from these isogenic flocculent and non-flocculent strains have been analyzed by SDS-polyacrylamide gel electrophoresis. A single polypeptide was missing in the non-flocculent strains. The isolation and characterization of this polypeptide are described.

\section{MATERIALS AND METHODS}

\subsection{Media and chemicals}

YPD consists of yeast extract (Difco) 10 g. $1^{-1}$, Bacto peptone (Difco) $20 \mathrm{~g} \cdot \mathrm{1}^{-1}$, and glucose $20 \mathrm{~g} \cdot \mathrm{1}^{-1}$. Media for the detection of nutritional requirements were minimal medium appropriately supplemented with nutrients as described by Zimmerman (24). Media were solidified with agar (Difco) $20 \mathrm{~g} \cdot 1^{-1}$.

All the common reagents were of analytical grade. Ergosterol was from British Drug House and Tween 80 was from Bie and Berntsen (Copenhagen). [125I] Sodium iodide was obtained from the Radiochemical Centre Ltd., Amersham, U.K., lactoperoxidase from Sigma (cat. no. L7129), snail enzyme was Suc-digestif d'Helix pomatia from L'industrie Biologique Francaise, Paris, France, fluorescein-conjugated antibodies from swine against rabbit serum were kindly provided by Dr. JOHN INGVERSEN of this department.

\subsection{Strains and crosses}

Strains used are shown i Table I. Crosses and tetrad analysis were carried out according to HAWTHORNE and MORTIMER (6). For all tetrads it was checked that nutritional characters segregated as expected. The segregation of mating type was determined whenever all four clones in a tetrad were auxotrophic.

\subsection{Measurement of flocculence}

Flocculence of the yeast strains were measured as previously described (9).

\subsection{Preparation of alkaline cell extracts}

Cells grown overnight (about $10^{3}$ cells.m- $\mathrm{m}^{-1}$ ) in $100 \mathrm{ml}$ YPD were washed once in $100 \mathrm{~mm}$ EDTA, twice in deionized water and resuspended in water to a total volume of $5 \mathrm{ml}$. One tenth $\mathrm{ml} 1 \mathrm{M}-\mathrm{NaOH}$ was added and the suspension was shaken at $30^{\circ} \mathrm{C}$ for 60 minutes. The cells were removed by centrifugation and the supernatant was neutralized with $1.1 \mathrm{ml} 1$ $\mathrm{M}-\mathrm{HCl}$ and put on ice. Then an equal volume $12.5 \%$ TCA $\left(0^{\circ} \mathrm{C}\right)$ was added and the tubes left overnight in the refrigerator. The precipitates were collected by centrifugation.

For the purification of the $13,000 \mathrm{MW}$ polypeptide, $100 \mathrm{mg}$ of crude extract were prepared with a modified procedure: Cells of the flocculent petite strain C77-M24-23/P1 were grown to stationary phase in 4.51 of YPD supplemented with ergosterol $\left(20 \mathrm{mg} \cdot 1^{-1}\right)$ and Tween $80\left(5 \mathrm{~g} \cdot 1^{-1}\right)$. The cells were shaken with 50 $\mathrm{mM}-\mathrm{NaOH}$ at $30^{\circ} \mathrm{C}$ for 100 minutes, collected by centrifugation, resuspended in $50 \mathrm{mM}-\mathrm{NaOH}$ and treated for another 100 minutes. The supernatant from the first treatment was discarded. The supernatant from the second treatment was precipitated with ten volumes of cold acetone and left overnight at $-20^{\circ} \mathrm{C}$. The precipitate, referred to as crude extract, was spun down, dissolved in $0.1 \mathrm{M}-\mathrm{NH}_{4} \mathrm{OH}$ and freezedried.

Abbreviations: YPD $=$ Yeast extract Peptone Dextrose SCE $=$ Sorbitol Citrate EDTA $;$ SDS = Sodium Dodecyl Sulfate; TCA $=$ Trichloro Acetic acid. 
Table

Yeast strains used in this study.

\begin{tabular}{|c|c|c|}
\hline Strain & Genotype & Source \\
\hline $\mathrm{C} 75-\mathrm{M} 24$ & a his4-24 FLO4 & Previous study (9) \\
\hline C77-M24-23 & $\alpha$ his4-24 FLO4 fsul-1 & Mutant of C75-M24 (9) \\
\hline C77-M24-13 & $\alpha$ his4-24 FLO4 fsu2-1 & Mutant of C75-M24 \\
\hline C77-SN1-8 & a his4-24 FLO4 NFa) & Mutant of C75-M24 \\
\hline C77-SK1-14 & a his4-24 FLO4 $\mathrm{NF}^{\mathrm{a})}$ & Mutant of C75-M24 \\
\hline C77-S65-2 & a his4-24 FLO4 NFa) & Mutant of C75-M24 \\
\hline C77-M24-32 & a his4-24 FLO4 NFa) & Mutant of C75-M24 \\
\hline C77-S1-10B & a adel flo 4 & Previous study (9) \\
\hline C77-SI-5D & a adel FLO4 & Previous study (9) \\
\hline C77-S49B-1A & a adel FLO4 fsu2-I & Spore from cross C77-M24-13x C77-S1-5D \\
\hline C77-M24-23/P1 & a his4-24 FLO4 fsul-l (rho-) & Petite of C77-M24-23 (9) \\
\hline C77-M24-23/P110 & a his4-24 FLO4 fsul-I (rho-) & Petite of C77-M24-23 (9) \\
\hline $\mathrm{C} 77-\mathrm{M} 24 / \mathrm{P} 3$ & a his4-24 FLO4 (rho-) & Petite of C75-M24 (9) \\
\hline C77-M24/P45 & a his4-24 FLO4 (rho-) & Petite of C75-M24 (9) \\
\hline
\end{tabular}

a) NF = non-flocculent

\subsection{Lactoperoxidase catalyzed iodination}

The procedure was a modification of that described by SHIN and CarRaway (21). Cells grown overnight (about $10^{8}$ cells $\cdot \mathrm{ml}^{-1}$ ) in $100 \mathrm{ml}$ YPD were washed once in $100 \mathrm{mM}-E D T A$ and twice in deionized water. The pellet was resuspended in $1.67 \mathrm{ml} 180 \mathrm{~mm}-\mathrm{NaCl}, 12$ mM-Tris-HCl, $12 \mathrm{mM}-\mathrm{KI} \mathrm{pH} 7.4,80 \mu \mathrm{llac}$ toperoxidase suspension (46 units) and $10 \mu \mathrm{l} \mathrm{car-}$ rier free [ $\left.{ }^{125} 1\right]$ sodium iodide were added. Twentyfive aliquots of $20 \mu \mathrm{l} 2.33 \mathrm{mM}-\mathrm{H}_{2} \mathrm{O}_{2}$ were added at 30 second intervals to the suspension, which each time was vigorously mixed. The reaction was stopped by adding $400 \mu 100 \mathrm{mM}-\mathrm{KI}$ and $3 \mathrm{ml} 150 \mathrm{~mm}-\mathrm{NaCl}, 10 \mathrm{~mm}$-Tris- $\mathrm{HCl} \mathrm{pH}$ 7.4. The labeled cells were washed three times with $15 \mathrm{ml} 150 \mathrm{mM}-\mathrm{NaCl}, 10 \mathrm{mM}-\mathrm{Tris}-\mathrm{HCl} \mathrm{pH}$ 7.4 before further use.

\subsection{Spheroplast formation}

The procedure was a combination of those described by SCHWENCKE et al. (19) and NEWLON and FANGMAN (15). Half of the preparation of the iodinated cells was suspended in $10 \mathrm{ml} 5 \mathrm{~mm}$-EDTA, $50 \mathrm{~mm}$-dithiothreitol, 0.1 $\mathrm{M}-\mathrm{Tris}-\mathrm{HCl} \mathrm{pH} 8.9$ and shaken at $30^{\circ} \mathrm{C}$ for 15 minutes. The cells were spun down and resus- pended in $9 \mathrm{ml}$ of $0.1 \mathrm{M}$-sodium citrate, 0.02 M-EDTA, 1.0 M-sorbitol pH 5.8 (SCE). One ml of snail enzyme was added and the suspension was incubated at $34^{\circ} \mathrm{C}$ with shaking. Incubation was stopped when $20 \mu$ lof the suspension added to $1 \mathrm{ml}$ of $10 \%$ SDS would give a clear solution. The spheroplasts were collected by centrifugation and washed twice in SCE. The supernatant, which contained the material released by the snail enzyme, and the spheroplasts were then treated with alkali as described under 3.4 .

\subsection{SDS-polyacrylamide gel electrophoresis}

Two different slab gel electrophoretic systems were employed. The first was a 7.5-15\% gradient of polyacrylamide as described by Chua and Bennoun (3). The second was $18 \%$ acrylamide according to LAEMMLI (12) with two of the modifications described by THOMAS and KORNBERG (23): The concentration of Tris buffer in the separating gel was increased to $0.75 \mathrm{M}$ and the electrode buffer was $0.05 \mathrm{M}$-Tris, $0.38 \mathrm{M}$-glycine and $0.1 \%$ SDS $\mathrm{pH} 8.3$. After electrophoresis all slabs were fixed for at least 1 hour in 50\% methanol $/ 7 \%$ acetic acid, stained in $0.025 \%$ Coomassie Brilliant Blue R 250 in the 
same solvent and destained in 30\% methanol $/ 7 \%$ acetic acid. For autoradiography the gel was dried onto a sheet of Whatman 3 MM filter paper using Slab Gel Dryer model SE 540 (Hoefer Scientific Instruments). A sheet of Ilford X-ray film (type Rapid R) was placed on top of the dried gel. The autoradiograph was developed with Ilford PQ Universal developer.

\subsection{Preparation of antiserum against intact cells of strain C75-M24}

Cells of strain C75-M24 grown to stationary phase in YPD were washed 6 times with sterile phosphate buffered saline (17), and resuspended in $0.9 \% \mathrm{NaCl}, 1.2 \%$ formaldehyde at a concentration of $2 \times 10^{8}$ cells $\cdot \mathrm{ml}^{-1}$. This suspension was injected as superficially as possible subcutaneously on the back of adult rabbits at 7 days intervals $0.1,0.2,0.3,0.4$ and $0.5 \mathrm{ml}$ doses. Seven days after the last injection, blood samples were taken from an ear vein. The serum was then tested for content of antibody against intact cells of C75-M24 by immunofluorescent staining as described by RICHARDS and COWLAND (18). If the serum did contain antibodies against the cell surface of C75-M24, then every 6 weeks $40 \mathrm{ml}$ of blood were taken, the rabbits having received a $0.5 \mathrm{ml}$ dose of antigen 10 days before each bleeding.

\subsection{Isolation of immunoglobulins from antiserum}

The isolation of immunoglobulins from the antiserum was performed as described by HARBOE and INGILD (5).

\subsection{Purification of the $13,000 \mathrm{MW}$ polypeptide}

Sephadex G-100 gel filtration: $100 \mathrm{mg}$ of dried crude extract was dissolved in $20 \mathrm{ml}$ of $0.1 \%$ ammonium bicarbonate $\mathrm{pH} 8.5,0.1 \%$ $\mathrm{NaN}_{3}, 0.5 \%$ SDS. After addition of $0.5 \mathrm{ml}$ 2-mercaptoethanol the sample was flushed with $\mathrm{N}_{2}$ and incubated at room temperature overnight. Insoluble material was removed by centrifugation. The supernatant was applied to a 5 $\times 90 \mathrm{~cm}$ column of Sephadex G-100 Fine, equi- librated with $0.1 \%$ ammonium bicarbonate $\mathrm{pH}$ $8.5,0.1 \% \mathrm{NaN}_{3}, 0.5 \%$ SDS (8). The column was eluted by gravity with the same buffer at a rate of $28 \mathrm{ml}$ per hour and $10 \mathrm{ml}$ fractions were collected. The transmission of the eluate at $280 \mathrm{~nm}$ was recorded using an LKB Uvicord II supplied with a $3 \mathrm{~mm}$ quarts flow cell. Aliquots taken from the fractions were dried under vacuum and analyzed for polypeptide composition by SDS-gel electrophoresis. Appropriate fractions were then pooled and freezedried. The dried powder was resuspended in $10 \mathrm{ml}$ of $0.1 \mathrm{M}-\mathrm{HCl}$. Forty $\mathrm{ml}$ of cold acetone were added, the precipitate was spun down and washed twice with $40 \mathrm{ml}$ of $10 \% 0.1 \mathrm{M}-\mathrm{HCl}, 90 \%$ acetone $\left(0^{\circ} \mathrm{C}\right)$. The pellet was dissolved in $0.1 \mathrm{M}-\mathrm{NH}_{4} \mathrm{OH}$, dialyzed against $3 \times 51$ of $0.1 \mathrm{M}-\mathrm{NH}_{4} \mathrm{OH}$ and freezedried.

Reduction and carboxymethylation of possible cysteine residues were carried out as described by HIRS (7) with the modification that the Tris-HCl buffer was replaced by Trisacetate (same $\mathrm{pH}$ ). After the reaction the sample $(1 \mathrm{ml})$ was dialyzed against $1 \times 21$ of 8 M-urea, 0.02 M-Tris-acetate pH 8.4.

DEAE-cellulose chromatography: The sample was applied to a $0.5 \times 6 \mathrm{~cm}$ DEAE-cellulose column (Whatman DE 52) equilibrated with 8 M-urea, $0.02 \mathrm{M}$-Tris-acetate $\mathrm{pH} \mathrm{8.4}$. The column was eluted with a $240 \mathrm{ml} 24$ hours exponential gradient of $\mathrm{NaCl}(0.0-0.2 \mathrm{M})$ in the same buffer. The gradient was generated with an LKB Ultrograd gradient mixer at a rate of $10 \mathrm{ml}$ per hour (using a peristaltic pump from LKB) and $1 \mathrm{ml}$ fractions were collected (Ultrorac 7000 fraction collector). Transmission at $280 \mathrm{~nm}$ was recorded. The collected fractions were measured at $220 \mathrm{~nm}$ using a Zeiss PMQ II spectrophotometer. Appropriate fractions were pooled, dialyzed against $3 \times 51$ of $0.1 \mathrm{M}-\mathrm{NH}_{4} \mathrm{OH}$ and freezedried.

\subsection{Amino acid analysis}

Polypeptides were hydrolyzed at $110^{\circ} \mathrm{C}$ in 6 $M$ redestilled $\mathrm{HCl}$ containing $0.1 \%$ phenol for 22 hours in evacuated ampoules and analyzed on a Durrum D-500 automatic amino acid analyzer. The results were not corrected for hydrolysis losses. 


\section{RESULTS}

\subsection{A polypeptide absent from a non-flocculent mutant}

Cells of the flocculent strain C75-M24 and the temperature sensitive non-flocculent mutant C77-M24-23 (9) from C75-M24 were shaken with $20 \mathrm{~mm}-\mathrm{NaOH}$ for 60 minutes at $30^{\circ} \mathrm{C}$ and removed by centrifugation. Polypeptides released from the cells into the $\mathrm{NaOH}$ were precipitated with TCA and analyzed on polyacrylamide slab gels containing SDS (Figure 1). At the restrictive temperature, the nonflocculent C77-M24-23 lacked a major low molecular weight protein (approx. 13,000 daltons) which was present in the extract from the flocculent C75-M24 and the mutant grown at the permissive temperature without shaking. The gel patterns of the two strains differ otherwise primarily in band intensities, which may be accounted for by a differential release of polypeptides, since it was found that C77-M24-23 releases more protein than $\mathrm{C} 75-\mathrm{M} 24$. Increasing the $\mathrm{NaOH}$ concentration to $50 \mathrm{~mm}$ and the extraction time to 90 minutes did not change the electrophoretic pattern significantly, but more protein was released from both strains.

\subsection{Polypeptide composition of other non-flocculent mutants}

The polypeptide composition of alkaline extracts of five other independently isolated non-flocculent mutants of C75-M24 (C77-M24-13, C77-SN1-8, C77-SK1-14, C77-S65-2 and C77-M24-32) was analyzed. They all showed the same single polypeptide difference when compared to C75-M24 as did C77-M24-23.

The mutants C77-M24-13 and C77-M24-32 were selected as previously described (9) after mutagenesis of C75-M24 with N-methyl-N'nitro-N-nitrosoguanidine to a survival level of $10 \%$ and $90 \%$ respectively. The mutants C77-SN1-8, C77-SK1-14 and C77-S65-2 were isolated after mutagenesis of C75-M24 with ethyl-methansulfonate (20) to a survival level of $10 \%$. Of these mutants only C77-M24-13 was analyzed genetically, since the other four did not produce asci with more than 1-2 viable spores when they were crossed and the result- ing diploids sporulated. Thus, C77-M24-13 was crossed to the non-flocculent strain C77-S1-10B (17o4, Table I): Six out of six asci showed one or more flocculent progeny demonstrating that

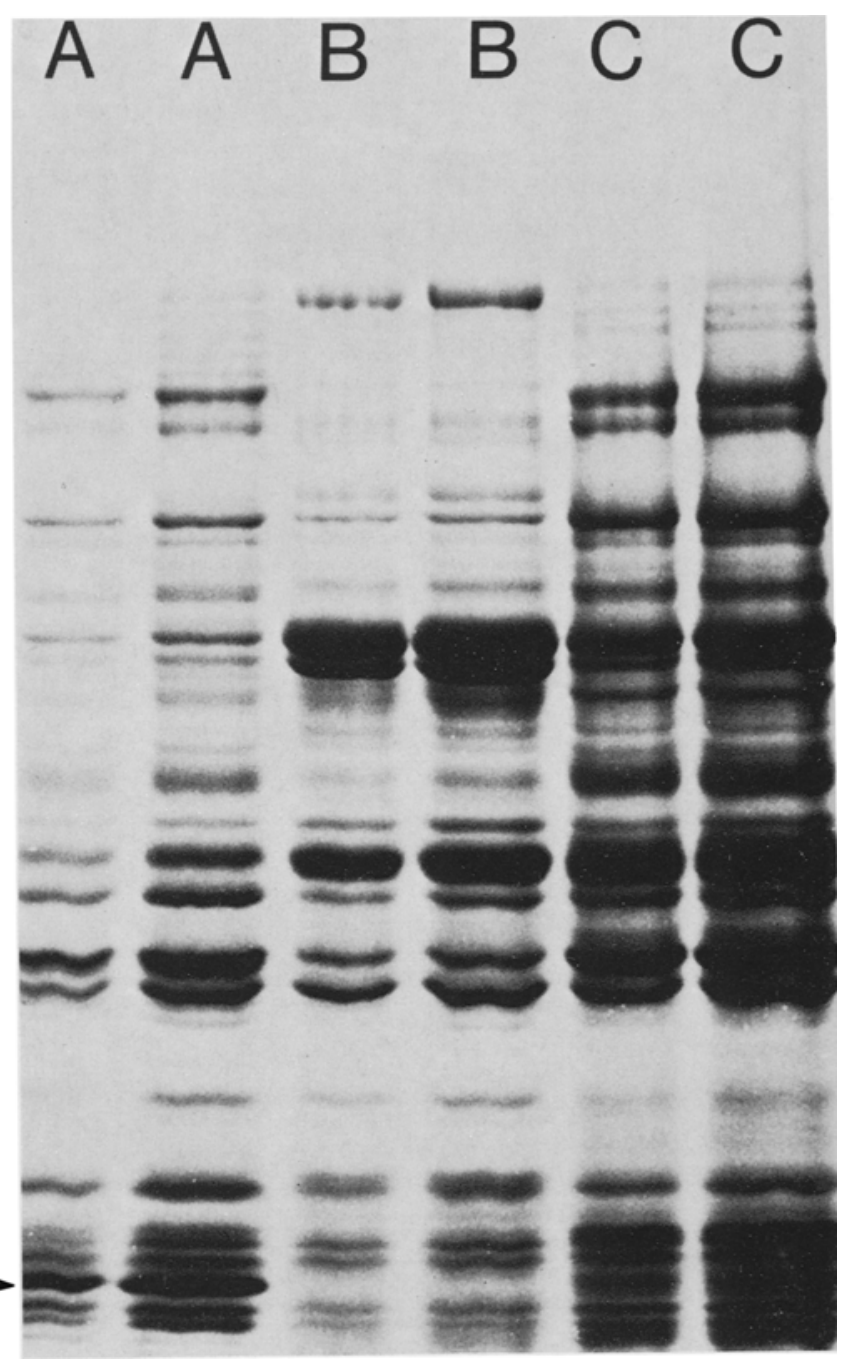

Figure 1. Gel electropherogram of alkaline extracts at two different concentrations from the flocculent strain $\mathrm{C} 75-\mathrm{M} 24$ (extracted with $50 \mathrm{mM}-\mathrm{NaOH}$, track A), the temperature sensitive non-flocculent mutant C77-M24-23 grown at $30^{\circ} \mathrm{C}$ (extracted with 20 $\mathrm{mM}-\mathrm{NaOH}$, track $\mathrm{B}$ ) and the mutant at the permissive $22^{\circ} \mathrm{C}$ (extracted with $50 \mathrm{mM}-\mathrm{NaOH}$, track $\mathrm{C}$ ). Note the absence of a polypeptide band in the 13,000 molecular weight region from the extract of the nonflocculent mutant at the restrictive temperature. 
the mutation in C77-M24-13 is not located in FLO4 but elsewhere in the genome. Secondly, to test if the change in C77-M24-13 represents a single gene mutation it was crossed to C77-S1-5D which also carries FL04. Six out of six asci showed 2:2 segregation for flocculence revealing that the mutation causing nonflocculence apparantly has taken place in a single gene. Thirdly, it was of interest to see if this mutation was different from $f$ sul (9). To test this, C77-M24-23 which is FL04, fsul, was crossed to C77-S49B-1A (Table I), which is also FLO4 and carries the suppressor mutation present in C77-M24-13. The analysis of 15 asci is presented in Table II. All asci yielded at least one flocculent progeny demonstrating that the two suppressor mutations have occurred in different unlinked loci. The new locus is called $f s u 2$ and the mutation $f_{s u 2-1}$. The wild type allele is correspondingly FSU2. It is noteworthy that both strain C77-M24-13 and strain C77-M24-23 are lacking the $13,000 \mathrm{MW}$ polypeptide although they contain different suppressors of FLO4.

\subsection{Polypeptide composition of petites differing in flocculation intensity}

The isolation and characterization of petites of the strains C75-M24 and C77-M24-23 has previously been described (9). Some of these petites had different flocculation phenotypes. $\mathrm{C} 77-\mathrm{M} 24 / \mathrm{P} 3$ and C77-M24/P45, a strongly and

\section{Table II}

Tetrad analysis of C77-M24-23 (a his4 FLO4 fsul) $\mathrm{x}$ C77-S49B-1A (a adel FLO4) NF.

\begin{tabular}{|c|c|c|}
\hline \multirow[t]{2}{*}{ Character } & \multicolumn{2}{|c|}{ Number of asci segregating } \\
\hline & $2: 2$ & $1: 3$ \\
\hline $\mathrm{F} / \mathrm{NF}$ at $30^{\circ} \mathrm{C}$ & 7 & 8 \\
\hline $\mathrm{a} / \alpha$ & 5a) & 0 \\
\hline$h i s / H I S$ & 15 & 0 \\
\hline ade/ADE & 15 & 0 \\
\hline
\end{tabular}

a) Only 5 asci were completely analyzed for mating type (cf, 2.5). a weakly flocculent petite of C75-M24 were analyzed. The low molecular weight polypeptide was present in the extract from C77-M24/P3 and displayed the same staining intensity in the gels as that of C75-M24, whereas it was only present in small amounts in the extract from C77-M24/P45. Similarly, in the extract from C77-M24-23/PI10, a non-flocculent petite of $\mathrm{C} 77-\mathrm{M} 24-23$, the polypeptide was lacking, but was present in large amounts in C77-M24-23/P1, a strongly flocculent petite of C77-M24-23. Thus, in this experiment, as in those reported above, a close correlation between flocculence and the presence of this polypeptide was observed.

\subsection{Localization of the polypeptide in the cell}

An experiment was designed to determine whether the polypeptide is localized at the yeast cell surface (Figure 2a). The cells from stationary cultures of the flocculent C75-M24 and the non-flocculent $\mathrm{C} 77-\mathrm{M} 24-23$ grown at $30^{\circ} \mathrm{C}$ in YPD were vectorially labeled with ${ }^{125} \mathrm{I}$ using the lactoperoxidase method (cf. 2.5). In both cases four different extracts were made from the iodinated cells as follows: An alkaline cell extract was made from one half of the cells of each strain using $20 \mathrm{mM}-\mathrm{NaOH}$ (fraction $\mathrm{A}$ in Figure 2a). Spheroplasts were prepared from the other half as described in 2.6. The supernatant, which contained the material released by the snail enzyme, was divided into two equal parts. One was given no further treatment (fraction B in Figure 2a) whereas the other was made $20 \mathrm{~mm}$ in $\mathrm{NaOH}$ and incubated at $30^{\circ} \mathrm{C}$ for 60 minutes (fraction $\mathrm{C}$ in Figure 2a). The spheroplasts were washed and treated with 20 mM-NaOH (fraction D in Figure 2a). The four extracts from each strain were precipitated with cold TCA (12.5\%) and sedimented. A large amount of the incorporated ${ }^{125} I$ was released from the cells by the $\mathrm{NaOH}$ treatment (Table III, fraction A). Incubation with the snail enzyme was equally effective to release ${ }^{125}$ I labeled material (Table III, fractions B and C), indicating a preferential labeling of surface components. The polypeptide composition of these four extracts derived from C75-M24 and C77-M24-23 respectively was analyzed by auto- 


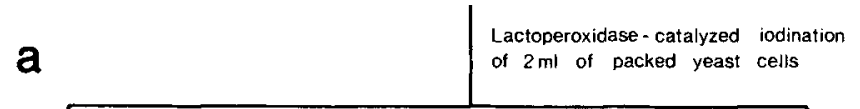

$1 \mathrm{ml}$ of packed labeled cells

incubated with $20 \mathrm{mM}-\mathrm{NaOH}$ for

60 minutes at $30^{\circ} \mathrm{C}$ with shaking
$1 \mathrm{ml}$ of packed labeled cells.

Spheroplast formation using

snail enzyme centrifugation

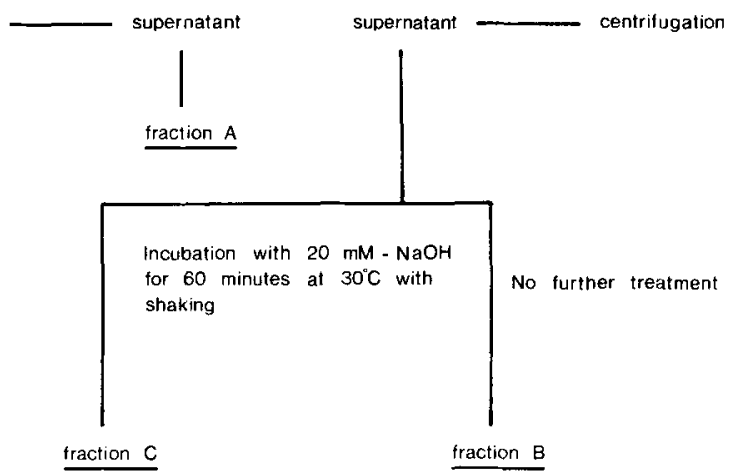

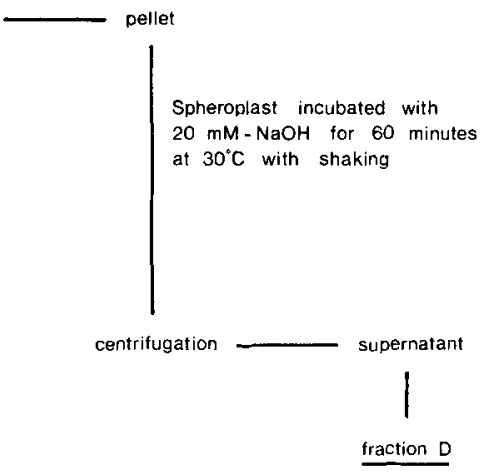
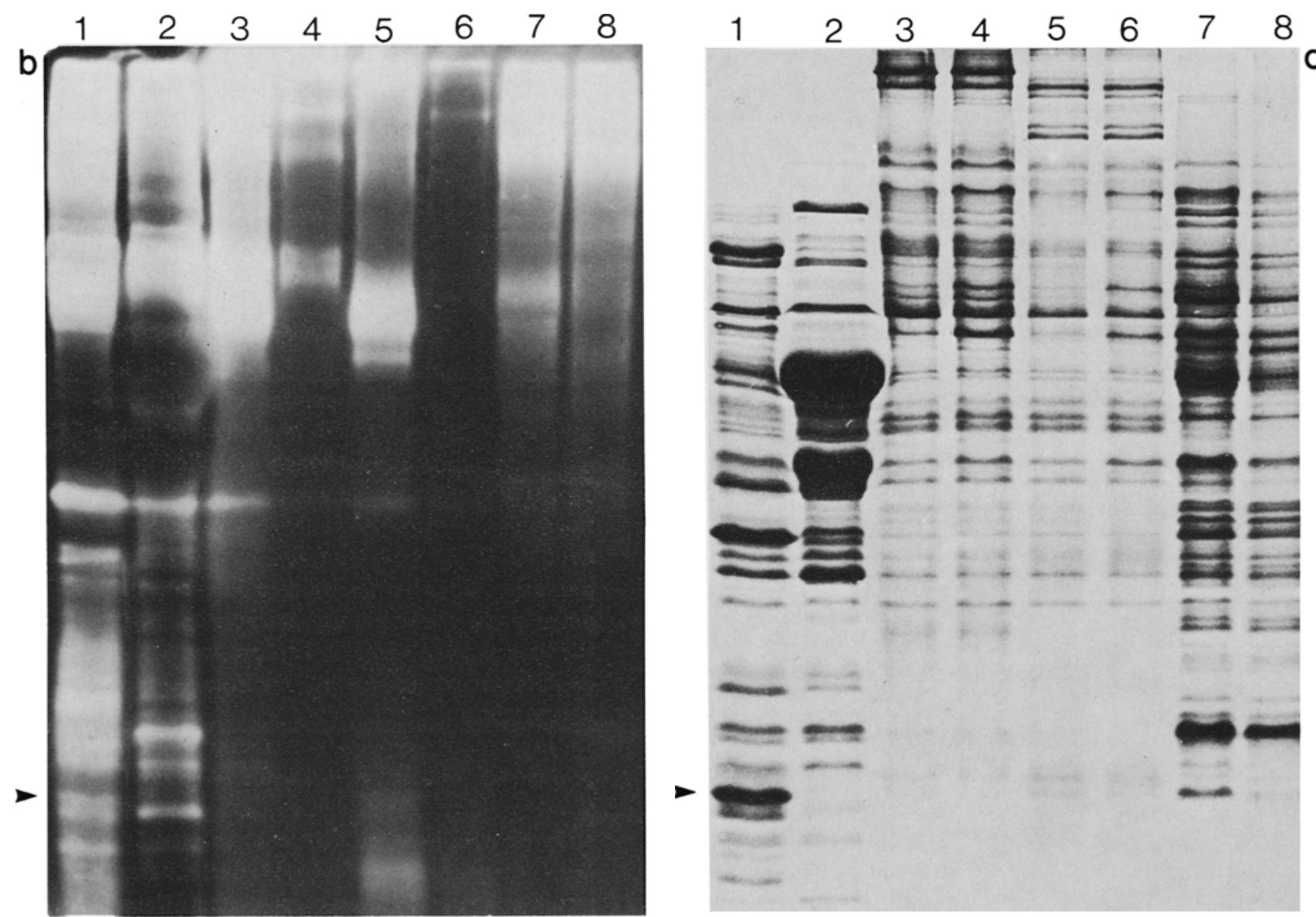

Figure 2. Localization of the $13,000 \mathrm{MW}$ polypeptide in the cell. a) Flow sheet of the fractionation procedure. The four fractions were analyzed by SDS-gel-electrophoresis. b) Autoradiograph of the gel. The arrow indicates the 13,000 MW polypeptide. Track 1: Fraction A from the flocculent strain C75-M24, track 2: Fraction $A$ from the non-flocculent mutant C77-M24-23, track 3: Fraction B, C75-M24, track 4: Fraction B, C77-M24-23, track 5: Fraction C, C75-M24, track 6: Fraction C, C77-M24-23, track 7: Fraction D, C75-M24, track 8: Fraction D, C77-M24-23. The autoradiograph was photographed with unequal exposure. c) Photograph of the stained gel. 
Table III

Release of ${ }^{123}$ from cells iodinated with the lactoperoxidase method.

\begin{tabular}{llc}
\hline & \multicolumn{2}{c}{ Radioactivity released in } \\
percent of the total radio- \\
Treatment & activity of the samples \\
& Strain & Strain \\
& C75-M24 & C77-M24-23 \\
\hline
\end{tabular}

$\mathrm{NaOH}$

(fraction A, Fig. 2)

64

60

Snail enzyme

(fractions B+C, Fig.2)

66

69

radiography of the polyacrylamide slab gel (Figure 2b) which showed that the low molecular weight polypeptide indeed was labeled with ${ }^{125}$ I in fraction A (Figure 2b, track 1). Several polypeptides identified in the gel by staining with Coomassie Brilliant Blue (Figure 2c) were not detectably labeled (Figure 2b), which is consistent with the notion that surface polypeptides were preferentially labeled. The 13,000 MW polypeptide was not present in the extract made by the snail enzyme or in fraction $\mathrm{C}$, i.e. after treatment of this extract with $\mathrm{NaOH}$ (Figure $2 \mathrm{~b}$, tracks 3 and 5 ). It is possible that the snail juice enzyme can not cleave the polypeptide from some carbohydrate component or that it digests the polypeptide. It was absent in the extract obtained from spheroplasts (Figure $2 b$, track 7). I take these results as evidence for an external location of the polypeptide in question.

\subsection{Immunochemical characterization of alkaline cell extracts}

Alkaline extracts of the flocculent strains C75-M24 and C77-M24-23/P1 and the nonflocculent strains C77-M24-13 and C77-M24-23 were analyzed by crossed immunoelectrophoresis using antiserum prepared against C75M24. This antiserum was obtained from rabbits after injection of intact stationary cells of C75-M24 as described in 2.8. The polypeptides were electrophoretically separated in a SDS- polyacrylamide gel by electrophoresis and then moved perpendicular to the first dimension into an agarose gel containing the purified IgG and IgA molecules (CHUA, N-H., personal communication). Figure 3a shows the precipitation pattern obtained in the analysis of the alkaline extract of C75-M24. Two precipitates (peaks B and $\mathrm{C}$ i Figure 3a) were observed in the molecular weight range of 57,000 and 40,000 daltons respectively and one (peak $A$ in Figure 3a) around 125,000 daltons, but no antigenantibody reaction was detected at the position of the 13,000 MW polypeptide. In the precipitation pattern of the alkaline extract of the nonflocculent cells of C77-M24-23 grown at restrictive conditions, peak $\mathrm{A}$ was missing whereas peak $B$ and $C$ were present (Figure 3b). The antigen giving rise to peak $A$ was likewise lacking from extracts derived from the non-flocculent C77-M24-13 as well as the flocculent C77-M24-23/P1. Although $f$ sul and $f s u 2$ causes the absence of peak $A$ the presence of this antigen is not required for flocculence since it is missing in C77-M24-23/P1, this strain being flocculent and containing the $13,000 \mathrm{MW}$ polypeptide.

\subsection{Purification of the $13,000 \mathrm{MW}$ polypeptide}

Preliminary experiments indicated that low molecular weight polypeptides were preferentially released by $\mathrm{NaOH}$ treatment of petite strains. A crude extract highly enriched in the 13,000 MW polypeptide was prepared from the flocculent petite strain C77-M24-23/P1 as detailed in 2.4 and analyzed by gel electrophoresis. Judged from staining intensities the polypeptide could account for approx. $30 \%$ of the total protein content. This preparation was used as starting material for the isolation of the polypeptide.

The crude extract was fractionated on Sephadex G-100 Fine in the presence of SDS. The elution profile as analyzed by SDS-polyacrylamide electrophoresis (Figure 4) showed fractions containing the polypeptide well separated from polypeptides with molecular weights higher than approximately 30,000 daltons. These fractions (108-120 in Figure 4) were pooled and concentrated by freeze-drying. 

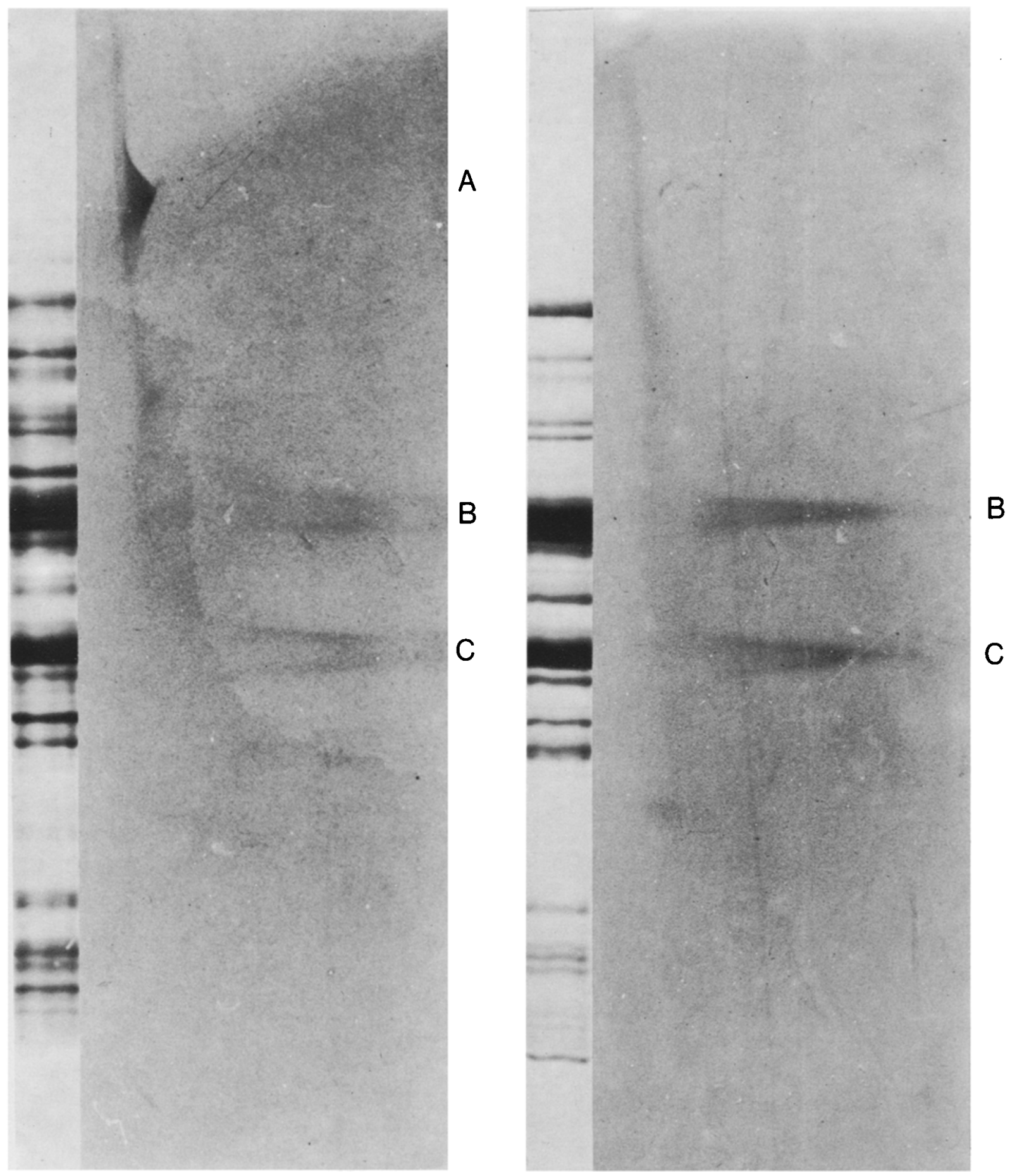

Figure 3. Crossed immunoelectrophoresis of alkaline extracts of the flocculent strain C75-M24 (3a) and the non-flocculent mutant C77-M24-23 (3b). The antiserum was from rabbits immunized with intact cells of the flocculent strain C75-M24. 


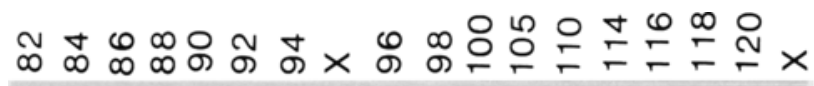

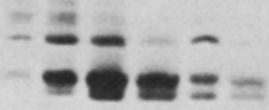

$13000 \mathrm{MW}-\overline{\bar{E}}$

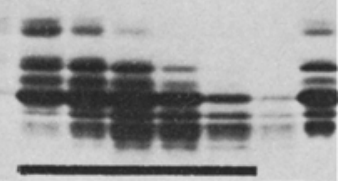

Figure 4. Gel electrophoretic analysis of fractions obtained by separation of $100 \mathrm{mg}$ crude extract containing the 13,000 MW polypeptide on Sephadex G-100 Fine in the presence of SDS. The fraction number is given above the tracks, those marked $X$ show the polypeptide composition of the crude extract. The region indicated by bar was pooled for DEAE-cellulose chromatography.

In order to eliminate interactions between SH groups, the sample was subjected to reducing conditions and treated with iodoacetic acid which would carboxymethylate any cysteine present in the polypeptide. The sample was then chromatographed on DEAE-cellulose in the presence of urea. The column was eluted with an exponential $\mathrm{NaCl}$ gradient. Three well separated peaks were obtained (Figure 5a). In Figure $5 b$ is shown the polypeptide composition of these three peaks as revealed by gel electrophoresis. Peak A represents the material not bound to the column. The two peaks $B$ and $C$ were eluted at $12 \mathrm{mM}$ and $20 \mathrm{mM}-\mathrm{NaCl}$ respectively. Peak B contained the $13,000 \mathrm{MW}$ polypeptide and two other very faint bands of higher and lower molecular weight. Peak C contained a polypeptide with slightly lower electrophoretic mobility as its major component. The purity of the preparation of the $13,000 \mathrm{MW}$ polypeptide in peak $\mathrm{B}$ is estimated from staining intensities to be over $90 \%$. From 4.51 of culture $100 \mathrm{mg}$ of crude extract was obtained, which in turn yielded approximately $500 \mu \mathrm{g}$ of the purified polypeptide.

\subsection{Amino acid analysis of the $13,000 \mathrm{MW}$ polypeptide}

The amino acid composition of the polypeptide is presented in Table IV. It is seen that the polypeptide has a high content of basic and acidic amino acids. No cystein was detected. From the amino acid analysis the polypeptide was calculated to consist of 121 residues yielding a molecular weight of 12,900 daltons. The relative high amount of lysine may account for the relative intense staining of the polypeptide with Coomassie Brilliant Blue.

\section{DISCUSSION}

With the aid of SDS-polyacrylamide gel electrophoresis (Figure 1) it was shown that alkaline extracts of the non-flocculent mutant C77-M24-23 lacked a low molecular weight polypeptide present in the extracts from the flocculent strain C75-M24. As the $\mathrm{NaOH}$ treatment may release both internal and external proteins from the cells, the location of the polypeptide was analyzed by labeling whole cells with ${ }^{125}$ I using lactoperoxidase, a procedure, which supposedly only labels the cell surface proteins (2). The results indicate that a vectorial labeling of polypeptides extractable by snail enzyme during spheroplast formation indeed took place (Table III). An equal amount of radioactivity was released by the $\mathrm{NaOH}$ treatment, which however also extracted nonlabeled proteins probably of intracellular origin. The presence of labeled 13,000 MW polypeptide in the alkaline extract strongly suggests its external location. It is possible that the alkaline extraction releases polypeptides covalently bound at the cell surface since alkali labile linkages between manno-oligosaccharides and serine and threonine residues are present in the cell wall (14). 
a
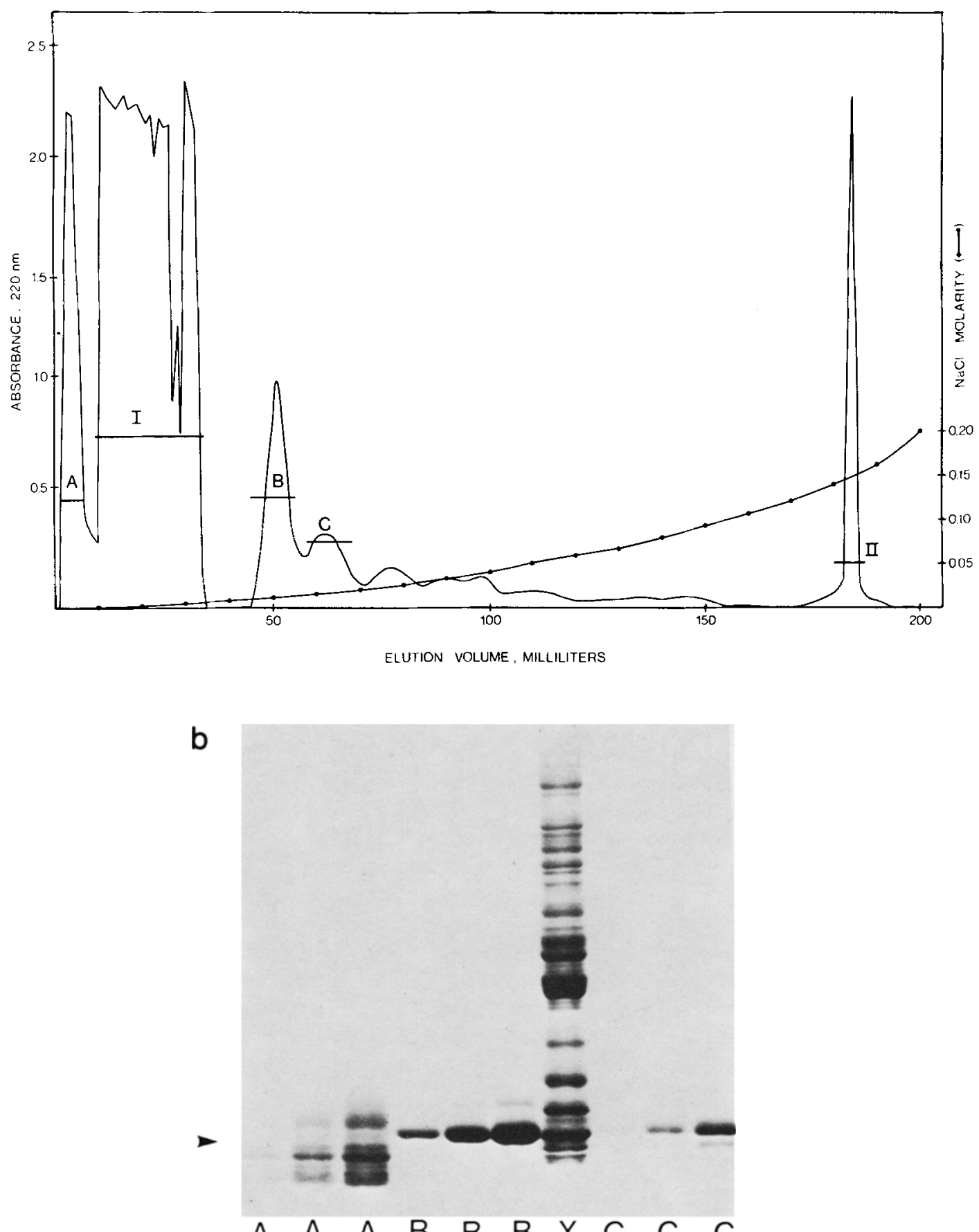

$\begin{array}{llllllllllllllllll}\text { A } & A & A & B & B & B & X & C & C & C\end{array}$

Figure 5. a) DEAE-cellulose chromatography of the pooled region from the gel filtration. Fractions were pooled as indicated by the bars and analyzed by SDS-gel-electrophoresis. The absorbing material in the regions I and II was not protein as revealed by SDS-gel-electrophoresis. b) Gel-electrophoretic analysis of the pooted regions $\mathrm{A}, \mathrm{B}$ and $\mathrm{C}$. The arrow indicates the $13,000 \mathrm{MW}$ polypeptide. A represents the material not bound to the column. $B$ and $\mathrm{C}$ were eluted at 12 and $20 \mathrm{~mm}-\mathrm{NaCl}$ respectively. The track marked $X$ shows the polypeptide composition of the $50 \mathrm{mM}-\mathrm{NaOH}$-extract from strain $\mathrm{C} 75-\mathrm{M} 24$. 
Table IV

Amino acid analysis of the $13,000 \mathrm{MW}$ polypeptide. Aspargine and glutamine was determined as arpartic and glumatic acid, respectively.

\begin{tabular}{ccc}
\hline Amino acid & Mole \% & $\begin{array}{c}\text { No. residues/ } \\
\text { polypeptide }\end{array}$ \\
\cline { 3 - 3 } Asx & 12.91 & 15 \\
Thr & 2.26 & 3 \\
Ser & 5.16 & 6 \\
Glx & 17.36 & 20 \\
Pro & 3.06 & 4 \\
Gly & 13.51 & 17 \\
Ala & 11.43 & 14 \\
Val & 6.59 & 8 \\
CmC & 0 & 0 \\
Met & 0.44 & 1 \\
Ile & 1.71 & 2 \\
Leu & 3.63 & 4 \\
Tyr & 3.29 & 4 \\
Phe & 2.29 & 3 \\
His & 2.12 & 3 \\
Lys & 11.59 & 14 \\
Arg & 2.64 & 3 \\
Trp & not determined & - \\
\hline
\end{tabular}

The absence of the polypeptide in the alkaline extract from both the non-flocculent mutant C77-M24-23 and five other independently isolated non-flocculent mutants demonstrates a correlation between the presence of the polypeptide and flocculence, which is supported by the presence of the polypeptide in C77-M24-23 after growth at conditions permissive for flocculation, and the polypeptide composition of petites with different flocculation phenotypes. In two of the non-flocculent mutants the absence of the peptide was caused by different suppressor genes for FL04. Thus, with the strains studied no exception to the correlation has been found and it will be interesting to see if this correlation holds for other strains as well.

The antibodies used in the immunochemical characterization of alkaline cell extracts were obtained after injection of whole flocculent cells into rabbits. The principal immunogen of the yeast cell surface is mannano-protein (1). That the antiserum contained antibodies against the cell surface was verified by fluorescence staining of whole cells of C75-M24.
However, this does not exclude that antibodies against internal antigens were also present in the serum. Three precipitation peaks were observed when alkaline cell extracts of the flocculent C75-M24 were analyzed. The extracts from two non-flocculent mutants and one flocculent petite all lacked the precipitation peak with the highest molecular weight antigen. The absence of this peak is thus not strictly paralleled by non-flocculence and the absence of the 13,000 MW polypeptide.

On the cell the polypeptide may exist in an aggregated or multimeric form. When the alkaline extract was chromatographed on Sephadex G-100 in $0.1 \mathrm{M}-\mathrm{NH}_{4} \mathrm{OH}$ buffer, it eluted with a $K_{\mathrm{av}}$ smaller than expected from the electrophoretic mobility on SDS-polyacrylamide gels suggesting the presence of such aggregates. Gel filtration in the presence of SDS gave on the other hand the expected $K_{a v}$. That no cystein was detected is in agreement with the observation that no change in the mobility of the polypeptide on SDS-gels was observed if dithiothreitol was omittet from the sample buffer.

The amino acid analysis of the purified polypeptide showed a high content of basic and possible acidic amino acids. Two observations indicate that many of the glx and asx residues (Table IV) are acidic amino acids. Firstly, the polypeptide is soluble both in dilute ammonia and concentrated formic acid, and secondly, the solubility of the polypeptide is very low at $\mathrm{pH}$ about 6 . Future investigations of the polypeptide may tell if the acidic amino acid residues function as anionic groups in the $\mathrm{Ca}^{++}$ dependent flocculation.

\section{ACKNOWLEDGEMENTS}

I wish to thank Dr. M. C. KIELlandB randt, Dr. T. Nilsson-Tillgren, cand. polyt. J. G. LITSKe PETERSEN and cand. scient. C. Poulsen for advice and fruitful discussions, professor D. vON WETTSTEIN for support and encouragement, Ms. S. HoLDER for excellent technical assistance with the immunochemical work and Ms. B. CORNELIUSEN for performing the amino acid analysis. 


\section{REFERENCES}

1. Ballou, C. E. \& W. C. Raschke: Polymorphism of the somatic antigen of yeast. Science 184, 127-134 (1974)

2. Carraway, K. L.: Covalent labeling of membranes. Biochim. Biophys. Acta 415, 379-410 (1975)

3. ChuA, N.-H. \& P. Bennoun: Thylakoid membrane polypeptides of Clamydomonas reinhardtii: Wildtype and mutant strains deficient in photosystem II reaction centre. Proc. Nat. Acad. Sci. (USA) 72, 2175-2179 (1975)

4. Culbertson, M. R., L. Charnas, M. T. Johnson \& G. R. FINK: Frameshifts and frameshift suppressors in Saccharomyces cerevisiae. Genetics 86, 745-764 (1977)

5. HARBOE, N. \& A. INGILD: Immunization, isolation of immunoglobulins, estimation of antibody titre. In: A Manual of Quantitative Immunoelectrophoresis. Methods and Applications, N. H. Axelsen, J. Krøll and B. Weeke eds., Universitetsforlaget Oslo, pp. 161-164 (1973)

6. Hawthorne, D. C. \& R. K. Mortimer: Chromosome mapping in Saccharomyces: Centromerelinked genes. Genetics 45, 1085-1110 (1960)

7. HIRS, C. H. W.: Reduction and S-carboxymethylation of proteins. In: Methods of Enzymology, vol. XI, 199-203. C. H. W. Hirs ed., Academic Press, New York and London (1967)

8. Holder, A. A.: Ribulose 1,5-diphosphate carboxylase from Oenothera. Purification and a peptide mapping procedure for the subunits. Carlsberg Res. Commun. 41, 321-334 (1976)

9. Holmberg, S. \& M. C. Kielland-Brandt: A mutant of Saccharomyces cerevisiae temperature sensitive for flocculation. Influence of oxygen and respiratory deficiency on flocculence. Carlsberg Res. Commun. 43, 37-47 (1978)

10. JAYATISSA, P. M. \& A. H. Rose: Role of wall phosphomannan in flocculation of Saccharomyces cerevisiae. J, Gen. Microbiol. 96, 165-174 (1976)

11. Kusma, M.: Comparative biochemical studies of alcoholic fermentation with special reference to the flocculation phenomena in yeast cells. III. Cell surface substances of some varieties of brewery yeast. Rep. Res. Lab. Kirin Brewery Co., Yokohama 7, 7-14 (1964)

12. LAEMMLI, U. K.: Cleavage of structural proteins during the assembly of the head of bacterieophage T4. Nature 227, 680-685 (1970)

13. MILL, P. J.: The nature of interactions between flocculent cells in the flocculation of Saccharomyces cerevisiae. J. Gen. Microbiol. 35, 61-68 (1964)

14. Nakajima, T. \& C. E. Ballou: Characterization of the carbohydrate fragments obtained from Saccharomyces cerevisiae mannan by alkaline degradation. J. Biol. Chem. 249, 7679-7684 (1974)

15. Newlon, C. S. \& W. L. Fangman: Mitochondrial DNA synthesis in cell cycle mutants of Saccharomyces cerevisiae. Cell 5, 423-428 (1975)

16. Nishihara, H., T. Toraya \& S. FukUi: Effect of chemical modification of cell surface components of a brewer's yeast on the floc-forming ability. Arch. Microbiol. 115, 19-23 (1977)

17. Pierce, J. S.: Immunofluorescent staining technique for the detection of wild Saccharomyces contaminants in Saccharomyces cerevisiae. J. Inst. Brew. 79, 134-136 (1973)

18. Richards, M. \& T. W. Cowland: The rapid detection of brewery contaminants belonging to genus Saccharomyces by a serological technique. J. Inst. Brew. 73, 552-558 (1968)

19. SChWencke, J., N. Magaña-Schwencke \& J. LAPORTE: Yeast protoplasts from stationary and starved cells: Preparation, ultrastructure and vacuolar development. Ann. Microbiol. (Inst. Pasteur) 128A, 3-18 (1977)

20. Sherman, F., G. R. Fink \& C. W. Lawrence: Laboratory manual for a course in Methods in Yeast Genetics, Cold Spring Harbor Laboratory (1974)

21. Shin, B. C. \& K. L. Carraway: Lactoperoxidase labeling of erythrocyte membranes from the inside and outside. Biochim. Biophys. Acta 345, 141-153 (1974)

22. Stewart, G. G., I. F. Garrison, T. E. Goring, M. Meleg, P. Pipasts \& I. Russel: Biochemical and genetic studies on yeast flocculation. KemiaKemi (Helsinki) 3, 465-479 (1976)

23. Thomas, J. O.\& R. D. Kornberg: An octamer of histones in chromatin and free in solution. Proc. Nat. Acad. Sci. (USA) 72, 2626-2630 (1975)

24. Zimmermann, F. K.: Detection of genetically active chemicals using various yeast systems. In: Chemical Mutagens. Principles and Methods for their Detection, A. Hollaender ed., Plenum Press. New York-London, Vol. III pp. $209-239$ (1973) 